\title{
Токсичність МАРК у карциномах щитоподібної залози. Механізми пригнічення сигнального каскаду (огляд літератури та власних даних)
}

\begin{abstract}
Мета роботи: дослідження в пухлинах щитоподібної залози (ЩЗ) активності та експресії головної ефекторної протеїнкінази каскаду - ERK1/2.

Отримано переконливі докази того, що сигнальний каскад Ras/Raf/MEK/ERK (MAPK) сприяє проліферації і злоякісній трансформації клітин шляхом стимуляції клітинного росту і ділення, а також пригнічення апоптозу. Мітогенний МАРКкаскад пов’язує сигнали факторів росту на рецепторах клітинної поверхні з транскрипційними факторами AP-1, NF-кB, Ets, що приводить до індукції c-Fos, цикліну D1 i с-Мус. Ці фактори регулюють експресію генів, що контролюють виживання, ангіогенез, ріст, проліферацію і мобільність клітин. Однак гіперактивність цього каскаду в пухлинних тканинах може привести до сенесценції, затримки росту, апоптозу або посилення автофагії. Цей феномен назвали “токсичністю онкогенів”.
\end{abstract}

Ключові слова: онкогени; злоякісні пухлини; щитоподібна залоза; МАРК; морталін.

Характеристика МАPK/ERK-каскаду. Сигнальний шлях Ret/Ras/Raf/MEK/ERK розглядають як основний, що контролює поділ клітини [1]. Тому важливо було дослідити в пухлинах щитоподібної залози (ЩЗ) активність і експресію головної ефекторної протеїнкінази, яка входить до цього каскаду - ERK1/2. Сигнальний каскад активується низкою позаклітинних сигналів (гормони, фактори росту, хемокіни, нейротрансмітери), які розпізнаються відповідними рецепторними тирозинкіназами чи рецепторами, що асоційовані 3 G-білками. Активований G-білок Ras взаємодіє 3 протеїнкіназою Raf, яка ініціює фосфорилювання каскаду ERK. Мітогенний каскад Ret/Ras/Raf/ MEK/ERK пов'язує сигнали факторів росту на рецепторах клітинної поверхні з транскрипційними факторами AP-1, NF-кB, Ets, що призводить до індукції наступних компонентів цих каскадів, c-Fos, цикліну D1 і с-Мус. Ці чинники регулюють експресію генів, що контролюють такі важливі клітинні процеси, як виживання, ангіогенез, ріст, проліферація і рухливість клітин, зокрема і трансформованих [2, 3].

У випадку RTK фактори росту зазвичай викликають димеризацію рецепторів, що дозволяє цитозольним тирозинкіназним доменам об'єднуватися і фосфорилювати один одного (автофосфорилювання). Ці фосфорильовані залишки потім функціонують як докінг-сайти, що притягують інші сигнальні компоненти з SH2 (Src homology 2) чи PTB (phosphotyrosine binding) доменами - такі, як Shc, Grb2 (growth factor receptor-bound protein 2) та SoS (Son-of-sevenless), які, у свою чергу, активують невеликий GTP-зв'язуючий білок Ras. SoS peкрутується з цитозолю до мембрани за допомогою
Shc, Grb2 і діє як основний обмінний фактор гуанінових нуклеотидів (GEF). Він каталізує перетворення неактивного Ras-GDP в активний Ras-GTP [4]. Активований Ras взаємодіє з протеїнкіназою Raf, мобілізуючи iї до мембрани і активуючи, яка, у свою чергу, ініціює фосфорилювання каскаду ERK. Три компоненти цього шляху (Raf-1, MEK1/2 та ERK1/2) утримуються на мембрані клітини білком-скафолдом KSR1 (protein kinase suppressor of Ras). Всі початкові процеси передачі сигналу відбуваються на поверхні клітини, а наступний етап передачі інформації залежить від дифузії активованої ефекторної кінази (ERK1/2) від поверхні клітини до ядра [5].

Після фосфорилювання активована ERK1/2 залишає плазматичну мембрану, дифундуючи у цитоплазму, а потім у ядро, де вона фосфорилюється та активує ряд факторів транскрипції. Деякі з таргетних генів кодують компоненти сигнального шляху MAPK, такі, як МАРК фосфатазу 1 (МКР-1), яка утворює петлю зворотного зв’язку. Крім того, є дві родини білків Sprouty, які функціонують як інгібітори сигнального шляху МАРК [5].

Кінцеві результати функціонування цих сигнальних шляхів дуже залежать від часових аспектів, особливо від тривалості сигналу. Наприклад, тривала стимуляція необхідна для індукування проліферації клітин. Сигнальний каскад МАРК оперує авторегуляторними циклами, і таким чином, різні сигнальні шляхи можуть регулювати експресію власних сигнальних компонентів. Так, ERK може регулювати експресію MKP1.

Сигнальний шлях Ret/Ras/Raf/MEK/ERK часто активований у деяких пухлинах у результаті хромосомних транслокацій RET-РTC, мутацій 
BRAF (BRAFV600E), RAS, генів деяких рецепторів цитокінів або надмірної експресії нормальних і мутованих рецепторів, таких, як EGFR. В основі патогенезу раку ЩЗ також лежить неконтрольована активність різних сигнальних шляхів і насамперед - МАРК-каскаду [6 - 8].

До 70 \% пухлин, отриманих з фолікулярних тироцитів, виявляють генетичні або епігенетичні зміни у факторах сигнального шляху Ret/Ras/Raf/ MEK/ERK (MAPK), наприклад, мутації в BRAF i NRAS, а також у генах фосфатази PTEN і PI3K/ AKT-каскаду, а близько 20 \% випадків РТС демонструють хромосомні перебудови Ret/PTC. Конститутивно активні мутації Ret викликають близько 95 \% спадкових МТС і близько 50 \% випадків спорадичних МТС $[9,10]$.

Пригнічення цього каскаду специфічними інгібіторами посилює чутливість ракових клітин (в тому числі і раку ЩЗ) до хіміотерапії [11-14].

Результати проведених нами досліджень експресії та активації ERK (рис. 1) виявилися до певної міри несподіваними з огляду на підвищену експресію PCNA, яка вказує на суттєве посиленння проліферативних процесів у клітинах пухлин Щ3 [15 - 19]. Так, у тканині ПК і ФК, а також фолікулярних аденом вміст ERK1/2 був значно нижчим порівняно з таким у незміненій тканині залози. Найменшим це зниження відмічено для тканини неінкапсульованих ПК. Відповідно низькому рівню експресії ERK1/2, активність цієї кінази в тканині ПК, ФК і фолікулярної аденоми виявилася істотньо нижчою від її активності у незміненій тканин. Як і у випадку визначення експресії ферменту, найбільшу різницю між активністю ERK1/2 у пухлині та незміненій тканині спостерігали в інкапсульованих ПК і у ФК. При розрахунку величини активності ферменту до його вмісту отримані подібні результати; лише неінкапсульована ПК виявилася пухлиною, в якій активність ERK1/2 не відрізнялася від такої у незміненій тканині. Отже, експресія PCNA не корелює з кількістю і активністю ЕRK1/2. Навіть більше, виявлені протиріччя між проліферативними функціями ERK1/2 і низьким рівнем іï̈ експресії та активності в пухлинах Щ3 [15, 17-19].

Автори також вказували, що експресія PCNA помітно посилювалась у ПК порівняно з доброякісними неоплазмами. Однак фосфо-ERK1/2 була виявлена тільки у 8 випадках (4,8 \%) 3167 зразків ПК. Цікаво також, що на інтенсивність забарвлення та ядерну локалізацію ERK1/2 не впливала присутність чи відсутність мутації B-RAF V600E $[19,20]$.

Результати даних, які ми отримали, свідчать, що пригнічення сигнального каскаду Ret/Ras/Raf/

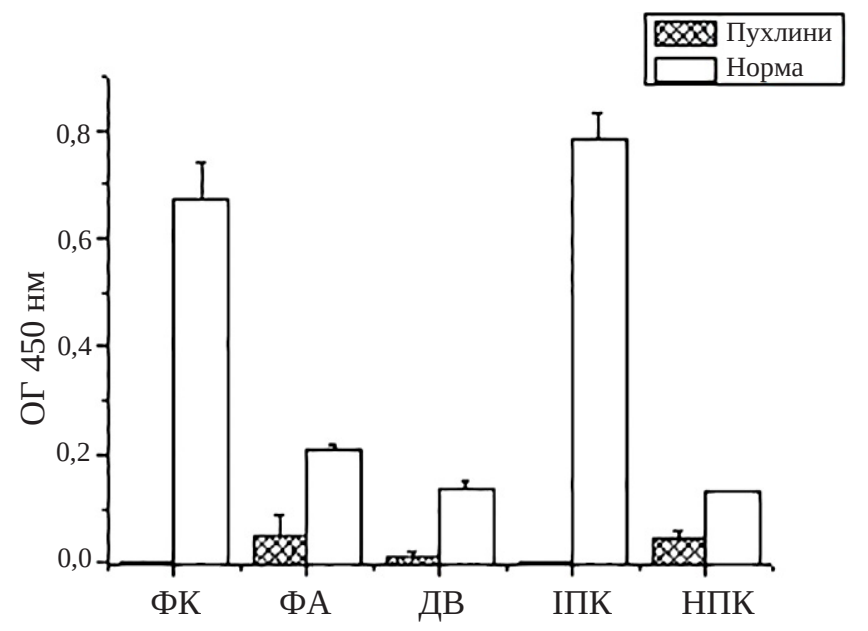

Рис. 1. Активація ERK1/2 у тканині папілярних, фолікулярних карцином, фолікулярної аденоми та зобнозміненій тканині щитоподібної залози.

Примітки: ФК - фолікулярна карцинома; ФА - фолікулярна аденома; ІПК - інкапсульована папілярна карцинома; НПК неінкапсульована папілярна карцинома; * - різниця відносно даних для незміненої тканини вірогідна $(\mathrm{P}<0,05)$.

MEK/ERK реалізується на рівні останньої протеїнкінази - ERK1/2. Таке пригнічення могло б відбуватися також на рівні другої протеїнкінази каскаду - MEК, проте той факт, що в пухлинах знижена не тільки активність, але й кількість ERK1/2 (чи за рахунок гальмування експресії, чи посилення деградації білка), свідчить, що саме ERK $є$ мішенню інгібуючих чинників.

Одержані дані свідчать про участь каскаду Ras/Raf/MEK/ERK у підтримці нормального росту клітин, у канцерогенезі та індукції лікарської стійкості до хімічних препаратів. Було показано, що онкогени пташиного і мишачого походження: ErbB, Ras, Src, Abl, Raf, PI3K, Akt, Jun, Fos, Ets i Rel - це клітинні гени, які були захоплені ретровірусами. Подальші дослідження визначили роль цих онкогенів у клітинній трансформації. Деякі 3 них пов'язані з каскадами Ras/Raf/MEK/ ERK i Ras/PI3K/PTEN/PDK/Akt й ініціюють ці шляхи (BCR-Abl, ErbB) або є нижчими регуляторами у ланцюгу, які контролюють експресію генів (Jun, Fos, Ets, NF-кB) [6, 19, 21]. Було показано, що Ras/Raf/MEK/ERK сприяє проліферації і злоякісній трансформації стимулюючи ріст клітин і пригнічуючи апоптоз. Отримані дані свідчать, що мутація V600E гена B-Raf може посилювати проліферацію і трансформацію, клітин і часто виявляється при деяких злоякісних новоутвореннях, включно і рак Щ3 [6, 21]. Однак кілька років тому було виявлено, що гіперактивація B-Raf i c-Raf-1 сприяє зупинці клітинного циклу 
[22-24]. Отже, повинен існувати тригер, який визначає долю клітини - іiї злоякісну трансформацію або зупинку поділу.

Можливе пояснення невідповідності рівня проліферації та активності ERK отримано при вивченні активності та експресії МАРК у клітинах медулярної карциноми (МТС) ЩЗ людини. Було виявлено, що, хоча онкогени Ras i Raf часто беруть участь в трансформації клітин, у багатьох випадках конститутивні активація цього каскаду в пухлинних тканинах призводить до зупинки росту, старіння або апоптозу [25, 26].

Токсичність MAPK/ERK-каскаду. Одержані докази участі сигнального шляху Raf/MEK/ERK у зупинці клітинного циклу, сенесценції, апоптозу і пригніченні проліферації [19].

Активація шляху Ras/Raf/MEK/ERK може пригнічувати ріст ліній МTC людини TT і MZCRC-1. Інгібування росту, ініційоване цим каскадом, опосередковується індукцією експресії LIF (лейкемічного інгібіторного фактора) і подальшої активації JAK/STAT3, а також через інші механізми [25, 27]. Тривала активація шляху Raf/MEK/ ERK викликає зупинку росту, супроводжувану відповідними змінами регуляторів клітинного циклу - зниження фосфорилювання $\mathrm{pRb}$ та понижуюче регулювання Е2F1, підвищена експресія інгі-

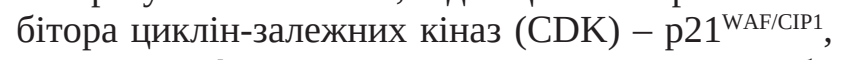
зміною морфології клітин та експресії с-Мус або RET у лініях пухлин людини LNCaP, U251 і TT [28]. Цікаво, що виключення ERK1 або ERK2 викликало тільки частковий ефект, тоді як для повного скасування Raf/MEK-залежної зупинки росту необхідне одночасне мовчання ERK1 і ERK2 $[19,28]$.

Ras/Raf-залежна експресія LIF спостерігалася також в інших типах клітин, включно первинні фібробласти і лінії дрібноклітинної карциноми легенів, у яких відбувається пригнічення росту у відповідь на гіперактивацію Ras/Raf. Було показано, що для LIF-індукованої зупинки росту необхідна експресія IFI16 (інтерферон-індуцибельний білок 16) [29]. Ras- або Raf-індуковані інгібуючі ріст реакції зараз сприймаються як важливі уроджені захисні механізми проти Ras/Raf-опосередкованого канцерогенезу. Було продемонстровано участь позаклітинних факторів в опосередкованому Ras/ Raf пригніченні росту. Так, клітини 3 Ras/Rafзалежним пригніченням росту секретують специфічні фактори - білок-7, що зв'язує інсуліноподібний фактор росту, інгібітор активатора плазміногену-1 і CXCR2-зв'язуючі хемокіни, такі, як інтерлейкін-8 або КС, які можуть посилювати інгібуючі клітинний ріст реакції [19, 27].
В ендотеліальних клітинах пупкової вени людини зупинка клітинного циклу в фазі G1 була пов'язана 3 посиленим фосфорилюванням ERK1/2, що, у свою чергу, визначало збільшення експресії інгібіторів клітинного циклу р21 ${ }^{\text {WAF/CIP1 }}$ та $\mathrm{p} 15^{\mathrm{INK} 4 \mathrm{~b}}$ [30].

Активація MEK/ERK блокувала індуковану IL-2 проліферацію Т-клітин через індукцію інгібітора CDK p21 ${ }^{\mathrm{WAF} / \mathrm{CIP} 1}$ або шляхом порушення активації STAT5. Крім того, активація MEK/ERK приводила до зупинки клітинного циклу, опосередкованої пригніченням експресії цикліну А і CDK2 [31].

Пригнічення фосфорилювання Сер777 в C-кінцевій області FGFR1 кіназами ERK1 і ERK2 посилювало FGF-стимульоване фосфорилювання тирозину рецептора, проліферацію та міграцію клітин [32].

Активність каскаду Raf/MEK/ERK пригнічується в деяких клітинних лініях раку простати, які мають мутації в гені PTEN. Крім того, шляхи Ras/ Raf/MEK/ERK i Ras/PI3K/PTEN/Akt також взаємодіють з сигнальним шляхом р53, що пов'язано з контролем активності і субклітинною локалізацією проапоптотичних факторів Bim, Bak, Bax, PUMA i Noxa. Raf/MEK/ERK сприяє зупинці клітинного циклу в клітинах простати, що може регулюватися р53, оскільки відновлення р53 дикого типу в р53-дефіцитних клітинах раку передміхурової залози призводить до посилення експресії Raf/MEK/ERK і підвищеної чутливості до хіміотерапевтичних засобів. Можливо, при розвинутому раку передміхурової залози необхідно індукувати експресію Raf/MEK/ERK, щоб сприяти зупинці клітинного циклу [6].

Форболовий ефір РМА - пухлинний індуктор, гіперактивує шлях MEK/ERK у клітинах раку молочної залози SKBr3, який, у свою чергу, індукує експресію $\mathrm{p}^{2} 1^{\mathrm{WAF} / \mathrm{CIP} 1} \mathrm{i}$ цикліну D1, викликаючи зупинку клітинного циклу на стадіях G1 i G2 з подальшим розвитком клітинної сенесценції. Показано, що надлишок цикліну D1 в клітинах з затримкою циклу є маркером сенесценції [33].

Активація Raf/MEK/ERK може викликати зупинку росту навіть в ракових клітинах із дефектними пухлинними супресорами - pRb, p53, $\mathrm{p} 16^{\mathrm{INK} 4 \mathrm{~A}}, \mathrm{p} 21^{\mathrm{WAF/CIP1}}$, а це передбачає, що множинні паралельні незалежні механізми пригнічення пухлини об’єднані в мережу з Raf/MEK/ERK [26].

Активність каскаду Ras/Raf/MEK/ERK може також викликати клітинну сенесценцію [34]. Хронічна експресія онкогенів або інактивація генів-супресорів пухлин у клітинах може ініціювати онкоген-індуковану сенесценцію (OIS) - спеціалізовану програму експресії генів, яка затримує 
клітини в метаболічно активному стані [35]. OIS вважається важливим механізмом супресії пухлин in vivo і включає дві родини онкогенов: Ras i Raf. OIS, ініційована мутантом Ras-онкогеном, служить зразковою моделлю сенесцентної відповіді [35, 36]. У нормальних культивованих клітинах гризунів і в більшості мишачих моделей сенесцентні фенотипи, викликані конститутивно активними білками Raf або Ras, реалізуються через p19ARF-p53 або p16 ${ }^{\mathrm{INK} 4 \mathrm{~A}}$-pRb. Експресія конститутивно активних мутантних Ras (NRas ${ }^{661 R K}$, $\left.H_{R a s^{G 12 V}}\right)$ або $B$-Raf (B-Raf $\left.{ }^{9600 e}\right)$ у нормальних людських меланоцитах приводила до класичної сенесцентної відповіді, опосередкованої PI3K, pRb, p53, UPR (unfolded protein response) для Rasіндукованої OIS і MEK, ERK, IGFBP7, IL-6, IL-8, p53 для B-Raf-індукованої OIS [37]. Нещодавно було показано, що автофагія, важливий гомеостатичний механізм для деградації довгоживучих або пошкоджених макромолекул, сприяє Rasіндукованій сенесценції [38], а пригнічення ключових генів автофагії порушує розвиток викликаної Ras сенесценції. Ці дані свідчать про те, що автофагія необхідна для прискорення обороту білків і полегшення індукції сенесценції у відповідь на сильний онкогенний стрес [19, 36].

Збільшення кількості фосфорильованої ERK (pERK) було продемонстровано в декількох K-Ras-залежних доброякісних новоутвореннях, що свідчить про кореляцію рівня рERK з маркерами клітинної сенесценції, такими, як р16 $16^{\mathrm{INK} 4 \mathrm{~A}}$, p19ARF, p53 і промієлоцитарний лейкозний білок. Ці спостереження свідчать про те, що ERK активує гени-супресори пухлин і для ініціювання росту пухлини в клітинах із підвищеними рівнями pERK необхідно виключення цих генів [23, 24].

При Ras-індукованій сенесценції аберантна передача сигналів через ERK приводила до деградації в протеасомах багатьох фосфопротеїнів, необхідних для росту клітин і прогресування клітинного циклу. Цей процес називається деградація асоційованих із сенесценцією білків (SAPD). SAPD залежала від активації ERK, а також спостерігалася при сенесценції, зумовленій укороченням теломер. Зниження активності ERK за допомогою інгібіторів або інтерферуючої РНК запобігало деградації білків і сприяло злоякісній трансформації експресуючим Ras клітинам [23, 24, 28]. На відміну від ERK1/2-залежної зупинки росту, припускається, що ERK2, але не ERK1, необхідна для індукції сенесценції онкогенним Ras [39].

Сигнальний шлях Ras/Raf/ERK часто $є$ розрегульованим у пухлинах у результаті активуючих мутацій в Ras або B-Raf, особливо в мелано- мах, пухлинах підшлункової та щитоподібної залоз, але все більше даних свідчить, що в певних умовах аберантна активація ERK може сприяти загибелі клітин. Проапоптотична функція каскаду Ras/Raf/ERK добре документована для апоптозу, зумовленого агентами, які пошкоджують ДНК, різними протипухлинними препаратами, TRAIL (TNF-related apoptosis-inducing ligand), важкими металами, токсичними сполуками, ROS i RNS як за внутрішньоклітинним (вивільнення цитохрому с з мітохондрій та активація каспази-9), так і за зовнішнім (активація каспази-8) шляхам реалізації апоптозу [40].

Цитотоксичний агент ангеліцин пригнічує ріст клітин NSCLC (Non-small-cell lung carcinoma) шляхом пригнічення регуляторів клітинного циклу - цикліну B1, цикліну E1 і Cdc2 і за рахунок зниження експресії МMP2/9 і збільшення експресії Е-кадгерину. Було показано, що фосфорилювання ERK1/2 і JNK1/2 збільшується паралельно 3 дією ангеліцину. Інгібування ERK1/2 і JNK1/специфічними інгібіторами значно послаблювало індуковані ангеліціном апоптоз, інгібування клітинного циклу і міграції [41].

Експерименти 3 використанням кадмію або TNF $\alpha$ показали зв'язок активації ERK із запрограмованою загибеллю клітин шляхом автофагії, а не 3 апоптозом. При нейродегенеративних захворюваннях активність ERK теж асоційована з загибеллю нейронів шляхом автофагії. Крім того, ERK також була пов'язана 3 автофагією і загибеллю клітин у багатьох клітинних моделях у відповідь на такі різні стреси, як недостатність амінокислот, соясапоніни, ліндан, дигідрокапсаїцин, кадмій і дію TNFa. Показано, що в клітинах раку яєчника людини цитоплазматична секвестрація ERK за допомогою астроцитарного фосфопротеїну PEA-15 сприяє розвитку автофагії. Більше того, при надекспресії конститутивно активної МЕК пряма активація ERK може сприяти автофагії без будь-яких інших стимулів [42].

ERK-залежна автофагічна активність пов'язана з класичними маркерами автофагії, такими, як індукція LC3 (microtubule-associated protein 1A/1B-light chain 3) і конверсія LC3-I в LC3-II, індукція беклінy-1, BNIP-3 (BCL2/adenovirus E1B 19 kDa proteininteracting protein 3) і активація G-взаємодіючого білка (GAIP) шляхом фосфорилювання Сер151. p53 також пов'язаний з процесом автофагії, оскільки опосередковане ERK фосфорилювання Сер392 в р53 бере участь в TNF-індукованій аутофагії [40]. 8-CEPQ (8-C-(E-phenylethenyl) quercetin) пригнічує ріст клітин раку товстої кишки, індукуючи загибель клітин шляхом автофагії через активацію ERK. По- 
казано, що ERK фосфорилює GAIP і стимулює автофагію [43]. У клітинах MCF-7 пригнічення ERK інгібітором PD98059 послаблює автофагію, індуковану TNF. Z-VAD-індукована загибель клітин може бути частково ослаблена U0126, інгібітором MEK1/2, вищенаведеної кінази щодо ERK1/2 [44]. U0126 блокує індуковане 8-CEPQ зниження життездатності в клітинах SW620 і НCT116, що свідчить про участь MEK/ERK в автофагії, зумовленої 8-CEPQ. Ці дані демонструють ключову роль ERK в опосередкованому 8-CEPQ процесі автофагії в клітинах раку товстої кишки [19, 43].

Сигнальний шлях Ras/Raf/ERK відіграє ключову роль в опосередкуванні декількох форм загибелі клітин у відповідь на стресові стимули як in vitro на різних клітинних моделях, так і in vivo. Загальною ознакою цієї відповіді є стійка активація ERK, що контрастує з тимчасовою стимуляцією ERK в ситуаціях, коли ERK регулює інші клітинні процеси. ERK-опосередкована смерть клітини пов'язана 3 дерегуляцією субклітинної локалізації активної кінази. Тривала цитоплазматична активність ERK сприяє сенесценції або автофагії, тоді як стійка ядерна секвестрація активності ERK може спровокувати апоптоз [40]. 3 огляду на важливість просторово-часової регуляції активності ERK для контролю клітинного поділу, індукція загибелі клітин може розглядатися як механізм негативного зворотного зв'язку, що запобігає неконтрольованій клітинній проліферації. Оскільки тривала активація ERK сприяє загибелі ракових клітинних ліній людини різного походження, ця властивість каскаду Ras/RAF/ERK може бути використана для впливу на ракові клітини. Однак відомо, що пухлинні клітини уникають індукованої Ras/RAF/ERK сенесценції шляхом інактивації її ефекторів, таких як р53 або р16 $6^{\text {INK4A }}$. Механізми, пов'язані із загибеллю клітин, викликаної ERK, також можуть бути заглушені в ракових клітинах. Пухлинні клітини з високою активністю ERK можуть ремоделювати сигналінг кінази, щоб уникнути опосередкованої ERK загибелі $[19,40]$.

Як було зазначено, активація каскаду RAF/ MEK/ERK пригнічується також і в деяких клітинних лініях раку передміхурової залози. Таким чином, шлях RAF/MEK/ERK по-різному впливає на ріст, апоптоз, клітинний цикл і резистентність до лікарських засобів в клітинах різних ліній, що може бути пов'язане з наявністю функціональних p53, PTEN і експресією специфічних для цих ліній факторів [6, 21]. Також було показано, що в деяких пухлинних клітинах базальні рівні активності MEK/ERK істотно нижче, ніж у фібробластах [26,
28]. Пригнічення експресії та активності ERK спостерігалося в пухлинах фолікулярної і папілярної карцином Щ3 [15, 17, 18]. Тому є цілком можливим, що активація RAF/MEK/ERK не забезпечує ростові процеси в цих типах пухлин, а пов'язані з каскадом механізми пригнічення пухлини не були інактивовані тиском онкогенного відбору [29, 28].

Необхідно зазначити, що у випадку раку легень, спричиненомy K-Ras, зменшення загальної кількості ERK за рахунок генетичної абляції ERK1 або ERK2 істотно не впливало на розвиток пухлини. Проте усунення обох ізоформ ERK порушувало розвиток пухлин, що передбачає необхідність хоча б невеликої кількості цих кіназ для процесу канцерогенезу [45].

Утримування ERK1/2 в цитоплазмі обмежує їі доступ до субстратів - факторів транскрипції, які відповідають за мітогенну відповідь. Крім того, цитозольні ERK1/2, інгібуючи проліферативні сигнали в ядрі, підсилюють каталітичну активність деяких проапоптотичних білків, таких, як DAPK (death-associated protein kinase) в цитоплазмі [46].

Механізми пригнічення MAPK/ERK-каскаду. Є дані, що ракові клітини індукують спеціальні захисні механізми проти токсичності онкогенів, як, наприклад, підвищення регуляції білка теплового шоку морталіну [47], які інгібують експресію та активацію ERK i, таким чином, захищають клітини пухлин від сенесценції, зупинки росту та апоптозу.

Морталін (HSPA9/GRP75/PBP74) належить до сімейства білка теплового шоку (HSP) 70, який також включає цитозольний споріднений білок теплового шоку 71 кДа (HSC70/HSPA8) і шаперон ендоплазматичного ретикулуму, BiP/HSPA5 [10]. Морталін відіграє істотну роль як шаперон, у мітохондріальному імпорті, реакції на оксидативний стрес, регуляції мембранного потенціалу мітохондрій, генерації енергії, внутрішньоклітинному транспорті, функціях р53, імунній відповіді і захисті від апоптозу та канцерогенезі [48]. Морталін міститься в багатьох субклітинних компартментах, включно мітохондрії, ендоплазматичний ретикулум, плазматичну мембрану, цитозоль і центросоми, а нещодавно був виявлений у сироватці хворих на колоректальний рак, і його підвищений рівень був визнаний як фактор ризику коротшої виживаності. Показано, що морталін присутній в ядрі ракових клітин, де він сприяє агресивності пухлини за допомогою механізмів, які включають інактивацію функцій р53 і активацію теломерази, гетерогенних рибонуклеопротеїнів K (hnRNP-K) і MMP [49].

Морталін часто надекспресується в різних типах пухлин, включно рак товстої кишки, печінки, 
мозку, молочної залози, шкіри і все більше даних свідчить про те, що він є важливим регулятором росту і виживання пухлинних клітин. Хоча морталін спочатку був ідентифікований як мітохондріальний молекулярний шаперон, він часто виявляється в різних субклітинних структурах ракових клітин, що вказує на його функціональну зміну при малігнізації $[10,50,51]$. Нещодавно повідомлялося, що кількість морталіну зростає в МТС людини та інтерференція з РНК або інгібування морталіну може ефективно пригнічувати клітинні лінії МТС в культурі, а також в ксенотрансплантатах миші [50, 51]. Суттєве зменшення вмісту морталіну викликало не тільки затримку росту, а й загибель клітин через порушення мітохондріальної біоенергетики та окиснювально-відновних балансів, що свідчить про його важливу для виживання роль в мітохондріях клітин МТС.

Профіль експресії морталіну в нормальних, різноманітних іморталізованих і пухлинних клітинних лініях виявили ї̈ двофазний характер: початкове зростання під час іморталізації, за яким йде апрегуляція, яка збігається з придбанням інвазивного фенотипу $[52,53]$. Протеомний аналіз масивів ракових тканин показав, що морталін $є$ прогностичним маркером колоректального раку [54]. Морталін виявляє посилене зв'язування з FGF-1, асоційоване з його фосфорилюванням і бере участь у регулюванні мітогенної активності ростового фактора [49].

Аналізи клітинних ліній і біопсійного матеріалу пухлини показують, що утворення морталіну підвищується не тільки в МТС, але і в РТС, FTC і АТС. Дослідження на клітинах МТС [50] і аналіз клітин АТС лінії С643 виявили морталін головним чином в мітохондріях, що підтверджує гіпотезу про те, що мітохондріальний морталін є критичним фактором для проліферації і виживання клітин у пухлинах щитоподібної залози шляхом впливу на біоенергетику органел і окисно-відновний баланс. Варто зауважити, що морталін також виявляється в різних субклітинних компартментах, особливо в клітинах раку, що свідчить про те, що його функціональну диверсифікацію. Так, морталін здатний секвеструвати ТР53 у цитозолі, що призводить до інактивації цього пухлинного супресора в різних типах пухлин [55, 56]. Морталін і р53 колокалізовані і взаємодіють в трансформованих, але не в нормальних, клітинах людини, що призводять до ядерної ексклюзії і транскрипційної інактивації р53 [56, 57]. Злоякісна трансформація клітин NIH 3Т3, продовження тривалості життя клітин MRC-5 і послаблення диференціювання клітин HL-60 шляхом надекспре- сії морталіну були пов'язані, принаймні частково, 3 транскрипційною інактивацією р53. Крім того, морталін інгібує р53-залежне пригнічення дуплікації центротросом, що призводить до анеуплоїдії - одна з ознак ракових клітин. Повідомлялося, що морталін утворює комплекси білок р53 в лейкемічних гемоцитах, але не взаємодіє в нормальних [49].

Морталін також впливав на активність Ras через його взаємодію з мевалонат-5-пірофосфат декарбоксилазою, ферментом, який біохімічно модифікує Ras. Незважаючи на те, що точна локалізація регуляторного впливу ще не 3'ясована, нещодавно було продемонстровано, що морталін негативно регулює активність шляху Raf/MEK/ ERK, сприяючи фізичній взаємодії між фосфатазою $1 \alpha$ і MEK1/2 [58]. Здатність морталіну модулювати шлях Raf/MEK/ERK є важливою для меланоми з B-Raf V600E і клітин раку товстої кишки з K-Ras G12V для обходу цитостатичних ефектів і пов'язана з високою активністю MEK/ERK [47]. Це спостереження не поширюється на ракові клітини щитоподібної залози з B-RafV600E, що вимагає подальшого дослідження. Враховуючи ці різноманітні ролі морталіну, існує можливість, що різні типи пухлинних клітин можуть використовувати різні аспекти функцій морталіну. Це частково може пояснити різний ефект нокдауну морталіну на регулятори клітинного циклу в клітинних лініях РТC і АТС. Варто зауважити, що патофізіологічні характеристики раку ЩЗ також визначаються специфічним генетичним фоном, наприклад, статусом мутацій TP53 або hTERT $[59,60]$.

Морталін може сприяти виживанню і росту пухлини за допомогою додаткових функцій. Як було визначено за фосфорилюванням активаційної петлі ERK1/2 (Тре202/Тир204 для ERK1 i Tpe183/Тир185 для ERK2), зниження кількості морталіну збільшувало активність MEK/ERK в клітинах MTC - TT і MZ-CRC-1. В подальших дослідженнях 3 використанням ТТ-клітин було виявлено, що зниження вмісту морталіну індукує тимчасову активацію MEK/ERK, спричиняючи пригнічення росту. Підвищувальна регуляція морталіну може сприяти виживанню і проліферації клітин МТС, ПК, ФК та АТС, регулюючи множинні паралельні незалежні клітинні процеси, включно метаболізм мітохондрій, сигналінг MEK/ ERK, експресію RET і активність p53 [10, 50].

Крім спеціальних захисних механізмів, які ракові клітини індукують проти токсичності МАРК/ ERK, існують і базові механізми, які контролюють каскад. Оскільки сигнальний шлях МАРК повинен бути інтегрований в загальну сигнальну ак- 
тивність клітини, то магнітуду, тривалість та локалізацію компонентів каскаду необхідно чітко контролювати для коректної відповіді на зовнішні і внутрішньоклітинні сигнали. Численні механізми були розвинуті для виконання цієї задачі, включно позитивні і негативні петлі зворотного зв’язку, як і велика кількість перехресних взаємодій між паралельними сигнальними шляхами. Механізми негативного зворотного зв'язку, орієнтовані на каскад МАРК, поділяються на дві основні категорії: пряма посттрансляційна модифікація компонентів сигнального шляху та індукція de поvо синтезу генів специфічних інгібіторів цих шляхів. Принциповою відмінністю між цими двома механізмами $є$ час, необхідний для реалізацію ефекту. Пряма посттрансляційна модифікація майже миттєва, експресія гена de поvо і синтез білка відбуваються з затримкою щодо початкової активації шляху [4].

Майже всі компоненти каскаду MAPK/ERK1/2 регулюються шляхом негативного зворотного фосфорилювання кіназами, що лежать нижче в сигнальному ланцюгу. Так, ERK1/2 безпосередньо фосфорилює декілька рецепторних тирозинкіназ. Наприклад, ERK1/2 може фосфорилювати рецептор епідермальний фактора росту (EGFR) по T669 - основний сайт фосфорилювання рецептора за залишками Ser/Thr, що призводить до пригнічення активації рецептора і всього сигнального шляху. Можливо, що те ж саме фосфорилювання контролює як тривалість ініціюючого сигналу, так і подальшу інтерналізацію рецептора. Рецептор фактора росту фібробластів (FGFR1) також є суб'єктом фосфорилювання ERK1/2 за консервативним залишком серину (S777) в його С-кінцевому хвості, що призводить до пригнічення фосфорилювання його тирозинових залишків [4].

Було виявлено, що активація МАРК призводить до гіперфосфорилювання адаптерного білка SOS1, яке посилювалось через надмірну експресію ERK і гальмувалось при інгібуванні MEK1/2. Показано, що SOS1 фосфорилюється активованим ERK2 по багатьох сайтах, що порушує його зв'язок з адаптерними білками Grb2 i Shc i, отже, з рецепторами. Білки субстрату 2 рецептора FGF (FRS2 $\alpha$ i FRS2 $\beta$ ) є адаптерними білками, які мобілізуються до активованого RTK через $\mathrm{N}$-кінцеві РТВ домени. Вони також містять декілька сайтів фосфорилювання тирозину в їх С-кінцях, що дозволяє зв'язувати адаптерний білок Grb2. Фосфорилювання треоніну FRS2 $\alpha$ кіназами ERK1/2 може являти собою консервативний механізм, за допомогою якого інгібується фосфорилювання тирозину FRS2 $\alpha$ і RTK-сигналінг [4].
Гіперфосфорилювання Raf-1 здійснювалося із затримкою порівняно до активації Raf-1, MEK1/2 i ERK1/2, і додатково посилювалося надекспресією ERK1, що вказує на існування негативного зворотного зв'язку. Подальші дослідження показали, що Raf-1 гіперфосфорилювання залежить від активності MEK1/2. Гіперфосфорильований Raf-1 демонструє знижену здатність до асоціації з плазматичною мембраною, що вказує на можливий механізм зворотного регулювання Raf-1. Були визначені шість сайтів Raf-1, які фосфорилюються після мітогенної стимуляції, п'ять з них фосфорилюються безпосередньо ERK2 [61].

Ідентифіковані сайти MEK1, включно Т286, T292 та Т386, пролін-спрямоване фосфорилювання яких пригнічує цю кіназу. Сайт Т292, можливо, відіграє вирішальну роль при інгібуванні активності MEK1. Показано, що Т292 фосфорилюється ERK1 i ERK2 і його фосфорилювання залежить від активності ERK1/2 в інтактних клітинах [62]. ERK1/2-залежне фосфорилювання MEK1 за T292 перешкоджає зв'язуванню MEK1 з ERK2, а також знижує здатність РАК (р21-активованої кінази) до фосфорилювання MEK1 pf S298, що необхідний для активації MEK1 шляхом клітинної адгезії [62].

Було показано, що ряд каркасних білків регулюють МАРК-сигналінг у клітинах ссавців, організовуючи сигнальні компоненти у високомолекулярні комплекси і таким чином посилюють ефективність та специфічність сигнального каскаду [63]. Білки KSR (kinase suppressor of Ras) $є$ найбільш вивченими щодо шляху MAPK/ERK1/2. Спочатку KSR1 було визначено як позитивний регулятор сигналінгу Ras. Подальші дослідження показали, що KSR1 взаємодіє з усіма трьома кіназами каскаду ERK1/2. Показано також, що KSR1 транслокується від цитозолю до плазматичної мембрани при стимуляції факторами росту, що дає підставу зібрати компоненти шляху МАРК (Raf, MEK1/2, ERK1/2) близько до вищезазначених активаторів (Ras). Ряд залишків KSR1 (T256, T260, T274, S320, S443, S463) фосфорилюються ERK1/2, що призводить до виходу KSR1 з плазматичної мембрани, тим самим погіршуючи здатність білка потенціювати передачу сигналу [4].

Таким чином, майже кожен етап МАРК-шляху - $є$ мішенню негативного фосфорилювання, від рецепторів факторів росту на плазматичній мембрані до основних компонентів каскаду, таких, як Raf-1/ B-Raf, MEK1/2) і каркасних білків, таких, як KSR1.

Крім швидкої регуляції шляхом прямого фосфорилювання вже існуючими протеїнкіназами, існують транскрипційно-індуковані механізми конт- 
ролю, які вмикаються з деякою затримкою і модулюють пізніші фази сигналінгу ERK1/2.

Для повної активації ERK1/2 небхідне фосфорилювання як треоніну, так і залишків тирозину в активаційній петлі кінази. Типи 1/2 Ser/Thr фосфатази, тирозин-протеїнфосфатази і Thr/Tyr фосфатази подвійної специфічності (DUSP) дефосфорилюють та інактивують ERK1/2. Найбільшою (10 видів) і найбільш вивченою групою фосфатаз, що специфічно регулюють активність МАРК, $€$ фосфатаза подвійної специфічності МАРК (МКР), що є підгрупою DUSP [64].

Багато членів родини DUSP можуть бути транскрипційно індуковані активацією шляху MAPK/ERK1/2, що дає можливість цим білкам відігравати важливу роль у регулюванні активності ERK1/2 шляхом її дефосфорилювання. Крім того, DUSPs можуть утримувати неактивні ERK1/2 в ядрі або цитоплазмі, потенційно затримуючи їх повторну активацію. Слід зазначити, що DUSPs діють тільки на ERK1/2 і не регулюють компоненти шляху, що стоять вище [65].

Інша група охарактеризованих транскрипійних інгібіторів ERK1/2 білки Spry, що були ідентифікованя як інгібітори Ras-сигналінгу нижче РТК [68-70]. Родина складається з чотирьох білків (Spry1-4), у той час як сімейство, пов'язане з Sprouty, SPRED (EVH1 domain-containing protein) містить три білки (SPRED1-3) разом з EVE-3, який $є$ варіантом сплайсингу SPRED3. Встановлена взаємодія між білками Spry і кількома компонентами шляху МАРК. Показано, що Spry1 i Spry2 фосфорилюются за консервативним N-кінцевим

\section{СПИСОК ЛІТЕРАТУРИ}

1. Wortzel I. The ERK cascade: distinct functions within various subcellular organelles / I. Wortzel, R. Seger // Genes Cancer. 2011. - Vol. 2 (3). - P. 195-209.

2. Beeram M. Raf: a strategic target for therapeutic development against cancer / M. Beeram, A. Patnaik, E. K. Rowinsky // J. Clin. Oncol. - 2005. - Vol. 23. - P. 6771-6790.

3. Mendoza M. C. The Ras-ERK and PI3K-mTOR pathways: cross-talk and compensation / M. C. Mendoza, E. E. Er, J. Blenis // Trends Biochem. Sci. - 2011. - Vol. 36 (6). - P. 320328. DOI:10.1016/j.tibs.2011.03.006.

4. Lake D. Negative feedback regulation of the ERK1/2 MAPK pathway / D. Lake, S. A. Corrêa, J. Müller // Cell Mol. Life Sci. 2016. - Vol. 73 (23). - P. 4397-4413.

5. Berridge M. J. Cell Signalling Pathways / M. J. Berridge // Cell Signalling Biology. - 2014. - 138 p. doi:10.1042/csb0001002.

6. Roles of the Raf/MEK/ERK pathway in cell growth, malignant transformation and drug resistance / J. A. McCubrey, L. S. Steelman, W. H. Chappell [et al.] // Biochem. Biophys. Acta. - 2007. Vol. 1773 (8). - P. 1263-1284.

7. Xing M. Molecular pathogenesis and mechanisms of thyroid cancer / M. Xing // Nat. Rev. Cancer. - 2013. - Vol. 13. - P. 184-199. залишком тирозину Y53 або Ү55, відповідно, при стимуляції EGF або FGF [78]. Фосфорилювання на цьому сайті створює сайт для стикування для SH2 домену Grb2, що призводить до порушення зв'язку між Grb2 і адаптером FGFR - FRS2. Таким чином, Spry може перешкоджати передачі сигналів вище Ras, але інші дані вказують, що Spry також може інгібувати шлях нижче Ras, можливо, шляхом зв'язування з Raf-1. Як і сімейство Spry, SPRED можуть зв'язуватися з Ras або Raf1, інгібуючи трансдукцію сигналу ERK $[4,5]$.

Отже, існує багато механізмів, які пригнічують сигналінг MAPK/ERK1/2 регулюванням шляхом негативного зворотного зв'язку. Вони включають відносно швидкодіючі механізми, а також механізми, що залежать від експресії білків de novo, які, у свою чергу, контролюють шлях ERK1/2 на декількох рівнях.

Таким чином, незважаючи на те, що шлях Raf/ MEK/ERK, головним чином, відомий завдяки ключовій ролі в підтримці виживання клітин і стимулюванні клітинного циклу у відповідь на мітогенні сигнали, каскад також може опосередковувати інгібування росту, загибель клітин і зупинку клітинного циклу в пухлинах у відповідь на численні сигнали [40, 46]. Такий антипроліферативний сигналінг цього каскаду має значення в різних фізіологічних умовах, включно ранній розвиток, диференціювання нейронів і реакцію пухлини на хіміотерапію. Останнім часом приділяється увага потенціалу Raf/MEK/ERK-опосередкованої зупинки росту як перспективного механізму супресії пухлин [26].
8. Xie J. Molecular mechanisms in differentiated thyroid cancer / J. Xie, Y. Fan, X. Zhang // Front Biosci. (Landmark ed.). - 2016. - Vol. 21. - P. 119-129.

9. Yakushina, V. D. Gene fusions in thyroid cancer / V. D. Yakushina, L. V. Lerner, A. V. Lavrov // Thyroid. - 2018. - Vol. 28 (2). - P. 158-167.

10. Mortalin (GRP75/HSPA9) promotes survival and proliferation of thyroid carcinoma cells / D. Starenki, N. Sosonkina, S. K. Hong [et al.] // Int. J. Mol. Sci. - 2019. - Vol. 20 (9). pii: E2069.

11. Molecular mechanisms of the effects of low concentrations of taxol in anaplastic thyroid cancer cells / V. M. Pushkarev, D. V. Starenki, V. A. Saenko [et al.] // Endocrinology. - 2004. Vol. 145 (7). - P. 3143-3152.

12. Участь МАРК у опосередкуванні дії протипухлинного препарату таксолу на клітини анапластичного раку щитоподібної залози / І. Д. Попадюк, В. М. Пушкарьов, Н. М. Костюченко, М. Д. Тронько // Доп. НАН України. - 2008. - № 2. - C. $174-177$.

13. Targeting RAS-MAPK-ERK and PI3K-AKT-mTOR signal transduction pathways to chemosensitize anaplastic thyroid carcinoma / Z. Milosevic, M. Pesic, T. Stankovic [et al.] // Transl. 
Res. - 2014. - Vol. 164 (5). - P. 411-423.

14. Sáez J. M. Treatment directed to signalling molecules in patients with advanced differentiated thyroid cancer / J. M. Sáez // Anticancer Agents Med. Chem. - 2013. - Vol. 13 (3). - P. 483-495.

15. The expression and activation of extracellular signal-regulated kinase-1/2 and proliferating cell nuclear antigen content in normal tissue and human thyroid tumors / B. B. Guda, V. M. Pushkarev, V. V. Pushkarev [et al.] // SM J. Endocrinol. Metab. - 2015. Vol. 1 (1). - Р. 1002.

16. Експресія ядерного антигену проліферуючих клітин (PCNA) в нормальних тканинах та доброякісних, високодиференційованих злоякісних (з наявністю метастатичного ураження та без метастазів) пухлинах щитоподібної залози людини / Б. Б. Гуда, В. В. Пушкарьов, О. В. Журавель [та ін.] // Доп. НАН України. - 2015. - № 10. - С. 93 - 97.

17. Активність протеїнкінази В та позаклітинної сигнал-регульованої кінази-1/2 в пухлинах щитоподібної залози, нормалізована щодо експресії протеїнкіназ в тканині / Б. Б. Гуда, В. М. Пушкарьов, А. Є. Коваленко [та ін.] // Проблеми ендокринної патології. - 2017. - № 2. - С. 38 - 43.

18. Role of mitogen-activated protein kinase (MAPK) in processes of proliferation in human thyroid tumors / B. B. Guda, V. M. Pushkarev, V. V. Pushkarev [et al.] // Endocrinology. 2016. - Vol. 21(1). - P. 5-9.

19. Toxicity of oncogenes in thyroid carcinomas and other tumor types / V. M. Pushkarev, B. B. Guda, V. V. Pushkarev, M. D. Tronko. // Cytology and Genetics. - 2018. - Vol. 52, No. 1. - P. 54-61.

20. Dual specificity phosphatase 6 as a predictor of invasiveness in papillary thyroid cancer / J. U. Lee, S. Huang, M. H. Lee [et al.] // European Journal of Endocrinology. - 2012. - Vol. 167. P. 93-101.

21. Targeting the Raf/MEK/ERK pathway with small-molecule inhibitors / J. A. McCubrey, M. Milella, A. Tafuri [et al.] // Curr. Opin. Investig. Drugs. - 2008. - Vol. 9 (6). - P. 614- 630.

22. Functional identification of tumor-suppressor genes through an in vivo RNA interference screen in a mouse lymphoma model / A. Bric, C. Miething, C. U. Bialucha [et al.] // Cancer Cell. 2009. - Vol. 16. - P. 324-335.

23. Tumor suppressor activity of the ERK/MAPK pathway by promoting selective protein degradation / X. Deschenes-Simard, M. F. Gaumont-Leclerc, V. Bourdeau [et al.] // Genes Dev. 2013. - Vol. 27. - P. 900- 915.

24. ERKs in cancer: friends or foes? / X. Deschenes-Simard, F. Kottakis, S. Meloche, G. Ferbeyre // Cancer Res. - 2014. Vol. 74 (2). - P. 412- 419.

25. The Ras/Raf/MEK/Extracellular signal-regulated kinase pathway induces autocrine-paracrine growth inhibition via the leukemia inhibitory factor/JAK/STAT pathway / J. I. Park, C. J. Strock, D. W. Ball, B. D. Nelkin // Mol. Cell Biol. - 2003. Vol. 23 (2). - P. 543-554.

26. Park J. I. Growth arrest signaling of the Raf/MEK/ERK pathway in cancer / J. I. Park // Front Biol. (Beijing). - 2014. Vol. 9 (2). - P. 95-103.

27. Arthan D. Leukemia inhibitory factor can mediate Ras/Raf/ MEK/ERK-induced growth inhibitory signaling in medullary thyroid cancer cells / D. Arthan, S. K. Hong, J. I. Park // Cancer Lett. - 2010. - Vol. 297 (1). - P. 31-41.

28. Noncatalytic function of ERK1/2 can promote Raf/MEK/ ERK-mediated growth arrest signaling / S. K. Hong, S. Yoon, C. Moelling [et al.] // J. Biol. Chem. - 2009. - Vol. 284 (48). P. 33006-330018.

29. Kim E. J. IFI16 is an essential mediator of growth inhibition, but not differentiation, induced by the leukemia inhibitory factor/ JAK/STAT pathway in medullary thyroid carcinoma cells /
E. J. Kim, J. I. Park, B. D. Nelkin // J. Biol. Chem. - 2005. Vol. 280. - P. 4913-4920.

30. BAG3 controls angiogenesis through regulation of ERK phosphorylation / A. Falco, M. Festa, A. Basile [et al.] // Oncogene. - 2012. - Vol. 31 (50). - P. 5153-5161.

31. Cell cycle arrest caused by MEK/ERK signaling is a mechanism for suppressing growth of antigen-hyperstimulated effector T cells / S. Ohtsuka, S. Ogawa, E. Wakamatsu, R. Abe // Int. Immunol. - 2016. - Vol. 28 (11). - P. 547-557.

32. ERK-mediated phosphorylation of fibroblast growth factor receptor 1 on Ser777 inhibits signaling / M. Zakrzewska, E. M. Haugsten, B. Nadratowska-Wesolowska [et al.] // Sci. Signal. - 2013. Vol. 6 (262). - ra11.

33. Leontieva O. V. Tumor promoter-induced cellular senescence: cell cycle arrest followed by geroconversion / O. V. Leontieva, M. V. Blagosklonny // Oncotarget. - 2014. - Vol. 5 (24). P. 12715-12727.

34. Cooperative effects of Akt- 1 and Raf- 1 on the induction of cellular senescence in doxorubicin or tamoxifen treated breast cancer cells / J. R. Taylor, B. D. Lehmann, W. H. Chappell [et al.] // Oncotarget. - 2011. - Vol. 2 (8). - P. 610-626.

35. Adams P. D. Healing and hurting: molecular mechanisms, functions, and pathologies of cellular senescence / P. D. Adams // Mol Cell. - 2009. - Vol. 36. - P. 2-14.

36. Subversion of autophagy by Kaposi's sarcoma-associated herpesvirus impairs oncogene-induced senescence / A. M. Leidal, D. P. Cyr, R. J. Hill [et al.] // Cell Host Microbe. - 2012. Vol. 11 (2). - P. 167-180.

37. Bansal R. Pathways of oncogene-induced senescence in human melanocytic cells / R. Bansal, M. A. Nikiforov // Cell Cycle. - 2010. - Vol. 9. - P. 2782-2788.

38. Autophagy mediates the mitotic senescence transition / A. R. Young, M. Narita, M. Ferreira [et al.] // Genes Dev. - 2009. - Vol. 23. - P. 798-803.

39. Depletion of ERK2 but not ERK1 abrogates oncogenic Rasinduced senescence / J. Shin, J. Yang, J. C. Lee, K. H. Baek // Cell Signal. - 2013. - Vol. 25 (12). - P. 2540-2547.

40. Cagnol S. ERK and cell death: mechanisms of ERK-induced cell death-apoptosis, autophagy and senescence / S. Cagnol, J. C. Chambard // FEBS J. - 2010. - Vol. 277 (1). - P. 2-21.

41. Angelicin inhibits human lung carcinoma A549 cell growth and migration through regulating JNK and ERK pathways / G. Li, Y. He, J. Yao [et al.] // Oncol. Rep. - 2016. - Vol. 36 (6). - P. 3504-3512.

42. Disruption of autophagy at the maturation step by the carcinogen lindane is associated with the sustained mitogenactivated protein kinase/extracellular signal-regulated kinase activity / E. Corcelle, M. Nebout, S. Bekri [et al.] // Cancer Res. 2006. - Vol. 66. - P. 6861-6870.

43. 8-C-(E-phenylethenyl)quercetin from onion/beef soup induces autophagic cell death in colon cancer cells through ERK activation / Y. Zhao, D. Fan, Z. Zheng [et al.] // Mol. Nutr. Food Res. - 2017. - Vol. 61 (2). doi: 10.1002/mnfr.201600437.

44. zVAD-induced autophagic cell death requires c-Src-dependent ERK and JNK activation and reactive oxygen species generation / S. Y. Chen, L. Y. Chiu, M. C. Ma [et al.] // Autophagy. - 2011. - Vol. 7. - P. 217-228.

45. c-Raf, but not B-Raf, is essential for development of K-Ras oncogene-driven non-small cell lung carcinoma / R. B. Blasco, S. Francoz, D. Santamaria [et al.] // Cancer Cell. - 2011. Vol. 19. - P. 652-663.

46. Mebratu Y. How ERK1/2 activation controls cell proliferation and cell death: Is subcellular localization the answer? / Y. Mebratu, Y. Tesfaigzi // Cell Cycle. - 2009. - Vol. 8 (8). - P. 1168-1175. 47. A Mortalin/HSPA9-mediated switch in tumor-suppressive 
signaling of Raf/MEK/Extracellular signal-regulated kinase / P. K. Wu, S. K. Hong, S. Veeranki [et al.] // Mol Cell Biol. 2013. - Vol. 33 (20). - P. 4051-4067.

48. Down-regulation of mortalin exacerbates $\alpha \beta$-mediated mitochondrial fragmentation and dysfunction / S. J. Park, J. H. Shin, J. I. Jeong [et al.] // J. Biol. Chem. - 2014. - Vol. 289. - P. 2195-2204.

49. Identification and functional characterization of nuclear mortalin in human carcinogenesis / J. Ryu, Z. Kaul, A. R. Yoon [et al.] // J. Biol. Chem. - 2014. - Vol. 289 (36). - P. 2483224844. doi: 10.1074/jbc.M114.565929.

50. Mortalin (GRP75/HSPA9) upregulation promotes survival and proliferation of medullary thyroid carcinoma cells / D. Starenki, S. K. Hong, R. V. Lloyd, J. I. Park // Oncogene. 2015. - Vol. 34 (35). - P. 4624-4634.

51. Starenki D. Selective mitochondrial uptake of MKT-077 can suppress medullary thyroid carcinoma cell survival in vitro and in vivo / D. Starenki, J. I. Park // Endocrinol. Metab. - 2015. Vol. 30. - P. 593-603.

52. Mortalin is a prognostic factor of gastric cancer with normal p53 function / K. Ando, E. Oki, Y. Zhao [et al.] // Gastric Cancer. - 2014. - Vol. 17. - P. 255-262.

53. Overexpression of Mortalin in hepatocellular carcinoma and its relationship with angiogenesis and epithelial to mesenchymal transition / J. Chen, W. B. Liu, W. D. Jia [et al.] // Int. J. Oncol. 2014. - Vol. 44. - P. 247-255.

54. Elevated levels of mitochondrial mortalin and cytosolic HSP70 in blood as risk factors in patients with colorectal cancer / P. Rozenberg, J. Kocsis, M. Saar [et al.] // Int. J. Cancer. - 2013. - Vol. 133. - P. 514-518

55. Iosefson O. A. Reconstitution of the mitochondrial Hsp70 (mortalin)-p53 interaction using purified proteins-identification of additional interacting regions / O. Iosefson, A. Azem // FEBS Lett. - 2010. - Vol. 584. - P. 1080-1084.

56. Mortalin-p53 interaction in cancer cells is stress dependent and constitutes a selective target for cancer therapy / W. J. Lu, N. P. Lee, S. C. Kaul [et al.] // Cell Death Differ. - 2011. Vol. 18. - P. 1046-1056.

57. Gestl E. E. Cytoplasmic sequestration of the tumor suppressor p53 by a heat shock protein 70 family member, mortalin, in human colorectal adenocarcinoma cell lines / E. E. Gestl, S. Anne Böttger // Biochem. Biophys. Res. Commun. - 2012. - Vol. 423. - P. 411-416.

58. Wu P. K. Steady-state levels of phosphorylated mitogenactivated protein kinase kinase 1/2 determined by mortalin/ HSPA9 and protein phosphatase $1 \alpha$ in KRAS and BRAF tumor cells / P. K. Wu, S. K. Hong, J. I. Park // Mol. Cell. Biol. - 2017. - Vol. 37 (18). pii: e00061-17.

59. Characterizing the three-dimensional organization of telomeres in papillary thyroid carcinoma cells / P. Caria, T. Dettori, D. V. Frau // J. Cell. Physiol. - 2019. - Vol. 234. - P. 5175-5185. 60. Effects of coexistent BRAFV600E and TERT promoter mutations on poor clinical outcomes in papillary thyroid cancer: A meta-analysis / S. Moon, Y. S. Song, Y. A. Kim [et al.] // Thyroid. - 2017. - Vol. 27. - P. 651-660.

61. Regulation of Raf-1 by direct feedback phosphorylation / M. K. Dougherty, J. Müller, D. A. Ritt [et al.] // Mol Cell. - 2005. - Vol. 17 (2). - P. 215-224.

62. Mitogen-activated protein kinase feedback phosphorylation regulates MEK1 complex formation and activation during cellular adhesion / S. T. Eblen, J. K. Slack-Davis, A. Tarcsafalvi [et al.] // Mol Cell Biol. - 2004. - Vol. 24 (6). - P. 2308-2317.

63. Brown M. D. Protein scaffolds in MAP kinase signalling / M. D. Brown, D. B. Sacks // Cell Signal. - 2009. - Vol. 21 (4). P. 462-469.

64. Caunt C. J. Dual-specificity MAP kinase phosphatases (MKPs) / C. J. Caunt, S. M. Keyse // FEBS J. - 2013. - Vol. 280 (2). - P. 489-504.

65. Huang C. Y. DUSPs, to MAP kinases and beyond / C. Y. Huang, T. H. Tan // Cell Biosci. - 2012. - Vol. 2 (1). - P. 24.

\section{REFERENCES}

1. Wortzel, I., \& Seger, R. (2011). The ERK cascade: distinct functions within various subcellular organelles. Genes Cancer, 2 (3), 195-209.

2. Beeram, M., Patnaik, A., \& Rowinsky, E.K. (2005). Raf: a strategic target for therapeutic development against cancer. J. Clin. Oncol., 23, 6771-6790.

3. Mendoza, M.C., Er, E.E., \& Blenis, J. (2011). The Ras-ERK and PI3K-mTOR pathways: cross-talk and compensation. Trends Biochem. Sci., 36 (6), 320-328. DOI:10.1016/j.tibs.2011.03.006. 4. Lake, D., Corrêa, S.A., \& Müller, J. (2016). Negative feedback regulation of the ERK1/2 MAPK pathway. Cell Mol. Life Sci., 73 (23), 4397-4413.

5. Berridge, M.J. (2014). Cell Signalling Pathways. Cell Signalling Biology, 138 doi:10.1042/csb0001002.

6. McCubrey, J.A., Steelman, L.S., Chappell, W.H., Abrams, S.L., Wong, E.W., Chang, F., ..., Franklin, R.A. (2007). Roles of the Raf/MEK/ERK pathway in cell growth, malignant transformation and drug resistance. Biochem. Biophys. Acta., 1773 (8), 12631284.

7. Xing, M. (2013). Molecular pathogenesis and mechanisms of thyroid cancer. Nat. Rev. Cancer, 13, 184-199.

8. Xie, J., Fan, Y., \& Zhang, X. (2016). Molecular mechanisms in differentiated thyroid cancer. Front Biosci. (Landmark ed.), 21, 119-129.

9. Yakushina, V.D., Lerner, L.V., \& Lavrov, A.V. (2018). Gene fusions in thyroid cancer. Thyroid, 28 (2), 158-167.

10. Starenki, D., Sosonkina, N., Hong, S.K., Lloyd, R.V., \& Park, J.I. (2019). Mortalin (GRP75/HSPA9) Promotes Survival and Proliferation of Thyroid Carcinoma Cells. Int. J. Mol. Sci., 26, 20 (9). pii: E2069.

11. Pushkarev, V.M., Starenki, D.V., Saenko, V.A., Namba, H., Kurebayashi, J., Tronko, M.D., \& Yamashita, S. (2004). Molecular mechanisms of the effects of low concentrations of taxol in anaplastic thyroid cancer cells. Endocrinology, 145 (7), 3143-3152.

12. Popadiuk, I.D., Pushkarov, V.M., Kostiuchenko, N.M., \& Tronko, M.D. (2008). Uchast MARK u oposeredkuvanni dii protypukhlynnoho preparatu taksolu na klityny ana-plastychnoho raku shchytopodibnoi zalozy [MAPK involvement in mediating the action of the anticancer drug taxol on anaplastic thyroid cancer cells]. Dop. NAN Ukrainy - Report of the NAS of Ukraine, 2, 174-177 [in Ukrainian].

13. Milosevic, Z., Pesic, M., Stankovic, T., Dinic, J., Milovanovic, Z., Stojsic, J., ..., Bankovic, J. (2014). Targeting RASMAPK-ERK and PI3K-AKT-mTOR signal transduction pathways to chemosensitize anaplastic thyroid carcinoma. Transl. Res., 164 (5), 411-423.

14. Sáez, J.M. (2013). Treatment directed to signalling molecules in patients with advanced differentiated thyroid cancer. Anticancer Agents Med. Chem., 13 (3), 483-495. 
15. Guda, B.B., Pushkarev, V.M., Pushkarev, V.V., Kovalenko, A. Ye., Taraschenko, Y.M., Kovzun, O.I. \& Tronko, M.D. (2015). The expression and activation of extracellular signalregulated kinase-1/2 and proliferating cell nuclear antigen content in normal tissue and human thyroid tumors. SM J. Endocrinol. Metab., 1 (1), 1002.

16. Huda, B.B., Pushkarov, V.V., Zhuravel, O.V., Kovalenko, A. Ye., Pushkarov, V.M., Zurnadzhy, L.Yu., ..., \& Tronko M.D. (2015). Ekspresiia yadernoho antyhenu proliferuiuchykh klityn (PCNA) v normalnykh tkanynakh ta dobroiakisnykh, vysokodyferentsiiovanykh zloiakisnykh (z naiavnistiu metastatychnoho urazhennia ta bez metastaziv) pukhlynakh shchytopodibnoi zalozy liudyny [Expression of proliferating cell nuclear antigen (PCNA) in normal tissues and benign, highly differentiated malignancies (with metastatic lesions and without metastases) in human thyroid tumors]. Dop. NAN Ukrainy - Report of the NAS of Ukraine, 10, 93-97 [in Ukrainian].

17. Huda, B.B., Pushkarov, V.M., Kovalenko, A.Ye., Pushkarov, V.V., Tarashchenko, Yu.M., Kovzun, O.I., \& Tronko, M.D. (2017). Aktyvnist proteinkinazy V ta pozaklitynnoi syhnalrehulovanoi kinazy-1/2 v pukhlynakh shchytopodibnoi zalozy, normalizovana shchodo ekspresii proteinkinaz v tkanyni [Protein kinase B activity and extracellular signal-regulated kinase-1/2 in thyroid tumors normalized to tissue kinase expression]. Problemy endokrynnoi patolohii - Problems of Endocrine Pathology, 2, 3843; 38-43 [in Ukrainian].

18. Guda, B.B., Pushkarev, V.M., Pushkarev, V.V., Kovalenko, A.Ye., Taraschenko, Y.M., Zhuravel, O.V., ..., \& Tronko, M.D. (2016). Role of mitogen-activated protein kinase (MAPK) in processes of proliferation in human thyroid tumors. Endocrinology, 21, 1, 5-9.

19. Pushkarev, V.M., Guda, B.B., Pushkarev, V.V., \& Tronko, M.D. (2018). Toxicity of oncogenes in thyroid carcinomas and other tumor types. Cytology and Genetics, 52, 1, 54-61.

20. Lee, J.U., Huang, S., Lee, M.H., Lee, S.E., Ryu, M.J., Kim, S.J., ..., \& Y.S. Jo. (2012). Dual specificity phosphatase 6 as a predictor of invasiveness in papillary thyroid cancer. European Journal of Endocrinology, 167, 93-101.

21. McCubrey, J.A., Milella, M., Tafuri, A., Martelli, A.M., Lunghi, P., Bonati, A., ..., \& Steelman, L.S. (2008). Targeting the Raf/MEK/ERK pathway with small-molecule inhibitors. Curr. Opin. Investig. Drugs, 9 (6), 614-630.

22. Bric, A., Miething, C., Bialucha, C.U., Scuoppo, C., Zender, L., Krasnitz, A., ..., \& Lowe, S.W. (2009). Functional identification of tumor-suppressor genes through an in vivo RNA interference screen in a mouse lymphoma model. Cancer Cell., 16, 324-335. 23. Deschenes-Simard, X., Gaumont-Leclerc, M.F., Bourdeau, V., Lessard, F., Moiseeva, O., Forest, V., ..., \& Ferbeyre, G. (2013). Tumor suppressor activity of the ERK/MAPK pathway by promoting selective protein degradation. Genes Dev., 27, 900915.

24. Deschenes-Simard, X., Kottakis, F., Meloche, S., \& Ferbeyre, G. (2014). ERKs in cancer: friends or foes? Cancer Res., 74 (2), 412-419.

25. Park, J.I., Strock, C.J., Ball, D.W., \& Nelkin, B.D. (2003). The Ras/Raf/MEK/Extracellular signal-regulated kinase pathway induces autocrine-paracrine growth inhibition via the leukemia inhibitory factor/JAK/STAT pathway. Mol. Cell Biol., 23 (2), 543-554.

26. Park, J.I. (2014a). Growth arrest signaling of the Raf/MEK/ ERK pathway in cancer. Front Biol (Beijing)., 9 (2), 95-103.

27. Arthan, D., Hong, S.K., \& Park, J.I. (2010). Leukemia inhibitory factor can mediate Ras/Raf/MEK/ERK-induced growth inhibitory signaling in medullary thyroid cancer cells. Cancer Lett., 297 (1), 31-41.
28. Hong, S.K., Yoon, S., Moelling, C., Arthan, D., \& Park, J.I. (2009). Noncatalytic function of ERK1/2 can promote Raf/MEK/ ERK-mediated growth arrest signaling. J. Biol. Chem., 284 (48), 33006-330018.

29. Kim, E.J., Park, J.I., \& Nelkin, B.D. (2005). IFI16 is an essential mediator of growth inhibition, but not differentiation, induced by the leukemia inhibitory factor/JAK/STAT pathway in medullary thyroid carcinoma cells. J. Biol. Chem., 280, 49134920.

30. Falco, A., Festa, M., Basile, A., Rosati, A., Pascale, M., Florenzano, F., ..., Turco, M.C. (2012). BAG3 controls angiogenesis through regulation of ERK phosphorylation. Oncogene, 20, 31 (50), 5153-5161.

31. Ohtsuka, S., Ogawa, S., Wakamatsu, E., Abe, R. (2016). Cell cycle arrest caused by MEK/ERK signaling is a mechanism for suppressing growth of antigen-hyperstimulated effector $\mathrm{T}$ cells. Int. Immunol., 28 (11), 547-557.

32. Zakrzewska, M., Haugsten, E.M., Nadratowska-Wesolowska, B., Oppelt, A., Hausott, B., Jin, Y., ..., \& Wiedlocha, A. (2013). ERK-mediated phosphorylation of fibroblast growth factor receptor 1 on Ser777 inhibits signaling. Sci. Signal., 6 (262), ra11.

33. Leontieva, O.V., \& Blagosklonny, M.V. (2014). Tumor promoter-induced cellular senescence: cell cycle arrest followed by geroconversion. Oncotarget., 5 (24), 12715-12727.

34. Taylor, J.R., Lehmann, B.D., Chappell, W.H., Abrams, S.L., Steelman, L.S., \& McCubrey, J.A. (2011). Cooperative effects of Akt-1 and Raf-1 on the induction of cellular senescence in doxorubicin or tamoxifen treated breast cancer cells. Oncotarget., 2 (8), 610-626.

35. Adams, P.D. (2009). Healing and hurting: molecular mechanisms, functions, and pathologies of cellular senescence. Mol. Cell., 36, 2-14.

36. Leidal, A.M., Cyr, D.P., Hill, R.J., Lee, P.W., \& McCormick, C. (2012). Subversion of autophagy by Kaposi's sarcomaassociated herpesvirus impairs oncogene-induced senescence. Cell Host Microbe., 11 (2), 167-180.

37. Bansal, R., \& Nikiforov, M.A. (2010). Pathways of oncogeneinduced senescence in human melanocytic cells. Cell Cycle., 9, 2782-2788.

38. Young, A.R., Narita, M., Ferreira, M., Kirschner, K., Sadaie, M., Darot, J.F., ..., Narita, M. (2009). Autophagy mediates the mitotic senescence transition. Genes Dev., 23, 798-803.

39. Shin, J., Yang, J., Lee, J.C., \& Baek, K.H. (2013). Depletion of ERK2 but not ERK1 abrogates oncogenic Ras-induced senescence. Cell Signal., 25 (12), 2540-2547.

40. Cagnol, S., \& Chambard, J.C. (2010). ERK and cell death: mechanisms of ERK-induced cell death-apoptosis, autophagy and senescence. FEBS J., 277 (1), 2-21.

41. Li, G., He, Y., Yao, J., Huang, C., Song, X., Deng, Y., ..., \& Liu, H. (2016). Angelicin inhibits human lung carcinoma A549 cell growth and migration through regulating JNK and ERK pathways. Oncol. Rep., 36 (6), 3504-3512.

42. Corcelle, E., Nebout, M., Bekri, S., Gauthier, N., Hofman, P., Poujeol, P., ..., Mograbi, B. (2006). Disruption of autophagy at the maturation step by the carcinogen lindane is associated with the sustained mitogen-activated protein kinase/extracellular signalregulated kinase activity. Cancer Res., 66, 6861-6870.

43. Zhao, Y., Fan, D., Zheng, Z.P., Li, E.T., Chen, F., Cheng, K.W., \& Wang, M. (2017). 8-C-(E-phenylethenyl)quercetin from onion/beef soup induces autophagic cell death in colon cancer cells through ERK activation. Mol. Nutr. Food Res., 61 (2), doi: 10.1002/mnfr.201600437.

44. Chen, S.Y., Chiu, L.Y., Ma, M.C., Wang, J.S., Chien, C.L., \& Lin, W.W. (2011). zVAD-induced autophagic cell death requires 
c-Src-dependent ERK and JNK activation and reactive oxygen species generation. Autophagy., 7, 217-228.

45. Blasco, R.B., Francoz, S., Santamaria, D., Cañamero, M., Dubus, P., Charron, J., ..., Barbacid, M. (2011). c-Raf, but not B-Raf, is essential for development of K-Ras oncogene-driven non-small cell lung carcinoma. Cancer Cell., 19, 652-663. 46. Mebratu, Y., \& Tesfaigzi, Y. (2009). How ERK1/2 activation controls cell proliferation and cell death: Is subcellular localization the answer? Cell Cycle., 8 (8), 1168-1175.

47. Wu, P.K., Hong, S.K., Veeranki, S., Karkhanis, M., Starenki, D., Plaza, J.A., \& Park J. I. (2013). A Mortalin/HSPA9-mediated switch in tumor-suppressive signaling of Raf/MEK/Extracellular signal-regulated kinase. Mol. Cell Biol., 33 (20), 4051-4067. 48. Park, S.J., Shin, J.H., Jeong, J.I., Song, J.H., Jo, Y.K., Kim, E.S., ..., \& Cho, D.H. (2014b). Down-regulation of mortalin exacerbates $\alpha \beta$-mediated mitochondrial fragmentation and dysfunction. J. Biol. Chem. 289, 2195-2204.

49. Ryu, J., Kaul, Z., Yoon, A.R., Liu, Y., Yaguchi, T., Na, Y., ..., Wadhwa, R. (2014). Identification and functional characterization of nuclear mortalin in human carcinogenesis. J. Biol. Chem., 289 (36), 24832-54844. doi: 10.1074/jbc.M114.565929.

50. Starenki, D., Hong, S.K., Lloyd, R.V., \& Park, J.I. (2015a). Mortalin (GRP75/HSPA9) upregulation promotes survival and proliferation of medullary thyroid carcinoma cells. Oncogene, 34 (35), 4624-4634.

51. Starenki, D., \& Park, J. I. (2015b). Selective mitochondrial uptake of MKT-077 can suppress medullary thyroid carcinoma cell survival in vitro and in vivo. Endocrinol. Metab., 30, 593-603.

52. Ando, K., Oki, E., Zhao, Y., Ikawa-Yoshida, A., Kitao, H., Saeki, H., \& Maehara, Y. (2014). Mortalin is a prognostic factor of gastric cancer with normal p53 function. Gastric Cancer, 17, 255-262.

53. Chen, J., Liu, W.B., Jia, W.D., Xu, G.L., Ma, J.L., Huang, M., ..., \& Li, J.S. (2014). Overexpression of Mortalin in hepatocellular carcinoma and its relationship with angiogenesis and epithelial to mesenchymal transition. Int. J. Oncol., 44, 247-255.

54. Rozenberg, P., Kocsis, J., Saar, M., Prohászka, Z., Füst, G., \& Fishelson, Z. (2013). Elevated levels of mitochondrial mortalin and cytosolic HSP70 in blood as risk factors in patients with colorectal cancer. Int. J. Cancer, 133, 514-518.
55. Iosefson, O., \& Azem, A. (2010). Reconstitution of the mitochondrial Hsp70 (mortalin)-p53 interaction using purified proteins-identification of additional interacting regions. FEBS Lett., 584, 1080-1084.

56. Lu, W.J., Lee, N.P., Kaul, S.C., Lan, F., Poon, R.T., Wadhwa, R., \& Luk, J.M. (2011). Mortalin-p53 interaction in cancer cells is stress dependent and constitutes a selective target for cancer therapy. Cell Death Differ, 18, 1046-1056.

57. Gestl, E.E., \& Anne Böttger, S. (2012). Cytoplasmic sequestration of the tumor suppressor $\mathrm{p} 53$ by a heat shock protein 70 family member, mortalin, in human colorectal adenocarcinoma cell lines. Biochem. Biophys. Res. Commun. 423, 411-416.

58. Wu, P.K., Hong, S.K., \& Park, J.I. (2017). Steady-state levels of phosphorylated mitogen-activated protein kinase kinase $1 / 2$ determined by mortalin/HSPA9 and protein phosphatase $1 \alpha$ in KRAS and BRAF tumor cells. Mol. Cell. Biol., 37 (18), pii: e00061-17.

59. Caria, P., Dettori, T., Frau, D.V., Lichtenzstejn, D., Pani, F., Vanni, R., \& Mai, S. (2019). Characterizing the three-dimensional organization of telomeres in papillary thyroid carcinoma cells. $J$. Cell. Physiol., 234, 5175-5185.

60. Moon, S., Song, Y.S., Kim, Y.A., Lim, J.A., Cho, S.W., Moon, J.H., ..., \& Park, Y.J. (2017). E ects of coexistent BRAFV600E and TERT promoter mutations on poor clinical outcomes in papillary thyroid cancer: A meta-analysis. Thyroid, 27, 651-660. 61. Dougherty, M.K., Mu“ller, J., Ritt, D.A., Zhou, M., Zhou, X.Z., Copeland, T.D., ..., Morrison, D.K. (2005). Regulation of Raf-1 by direct feedback phosphorylation. Mol. Cell, 17 (2), 215224.

62. Eblen, S.T., Slack-Davis, J.K., Tarcsafalvi, A., Parsons, J.T., Weber, M.J., \& Catling, A.D. (2004). Mitogen-activated protein kinase feedback phosphorylation regulates MEK1 complex formation and activation during cellular adhesion. Mol. Cell Biol., 24 (6), 2308-2317.

63. Brown, M.D., \& Sacks, D.B. (2009). Protein scaffolds in MAP kinase signalling. Cell Signal., 21 (4), 462-469

64. Caunt, C.J., \& Keyse, S.M. (2013). Dual-specificity MAP kinase phosphatases (MKPs). FEBS J., 280 (2), 489-504.

65. Huang, C.Y., \& Tan, T.H. (2012). DUSPs, to MAP kinases and beyond. Cell Biosci., 2 (1), 24.

Отримано 05.08.2019

Електронна адреса для листування: bguda@ukr.net

B. B. GUDA, V. V. PUSHKAREV, O. I. KOVZUN, V. M. PUSHKAREV, M. D. TRONKO

V. Komisarenko Institute of Endocrinology and Metabolism of the National Academy of Medical Sciences of Ukraine

\title{
TOXICITY OF MAPK IN THYROID CARCINOMA. MECHANISMS OF SUPPRESSION OF SIGNAL CASCADE (REVIEW OF LITERATURE AND OWN DATA)
}

\begin{abstract}
The aim of the work: to study the activity and expression of the main effector protein kinase cascade in tumors of thyroid gland. There is a strong evidence that the Ras/Raf/MEK/ERK (MAPK) signaling cascade promotes cell proliferation and malignancy by stimulating cell growth and division, as well as inhibiting apoptosis. The mitogenic MAPK cascade associates growth factor signals at cell surface receptors with the transcription factors AP-1, NF-kB, Ets, leading to the induction of c-Fos, cyclin D1 and c-Myc. These factors regulate the expression of genes that control survival, angiogenesis, growth, proliferation, and cell motility. However, the hyperactivity of this cascade in tumor tissues can lead to sensescence, growth retardation, apoptosis or increased autophagy. This phenomenon was called "oncogenic toxicity".
\end{abstract}

Key words: oncogenes; malignant tumors; thyroid gland; MAPK; mortalin. 
Б. Б. ГУДА, В. В. ПУШКАРЁВ, Е. И. КОВЗУН, В. М. ПУШКАРЁВ, Н. Д. ТРОНЬКО

ГУ “Институт ендокринологии и обмена веществ имени В. П. Комиссаренка НАМН Украины”

ТОКСИЧНОСТЬ МАРК В КАРЦИНОМАХ ЩИТОВИДНОЙ ЖЕЛЕЗЫ. МЕХАНИЗМЫ ПОДАВЛЕНИЯ СИГНАЛЬНОГО КАСКАДА (ОБЗОР ЛИТЕРАТУРЫ И СОБСТВЕННЫХ ДАННЫХ)

Цель работы: исследование в опухолях щитовидной железы активности и экспрессии главной эффекторной протеинкиназы каскада - ERK1/2.

Получены убедительные доказательства того, что сигнальный каскад Ras/Raf/MEK/ERK (MAPK) способствует пролиферации и злокачественной трансформации клеток путем стимуляции клеточного роста и деления, а также подавления апоптоза. Митогенный МАРК-каскад связывает сигналы факторов роста на рецепторах клеточной поверхности с транскрипционными факторами AP-1, NF-кB, Ets, что приводит к индукции c-Fos, циклина D1 и с-Мус. Эти факторы регулируют экспрессию генов, контролирующих выживание, ангиогенез, рост, пролиферацию и подвижность клеток. Однако гиперактивность этого каскада в опухолевых тканях может привести к сенесценции, задержке роста, апоптозу или усилению аутофагии. Этот феномен назвали “токсичностью онкогенов”.

Ключевые слова: онкогены; злокачественные опухоли; щитовидная железа; МАРК; морталин. 